\title{
Pengaruh Edukasi Media Whatsapp Tentang Gizi Laktasi, Involusi Uteri, Dan Lochea Terhadap Pengetahuan, Sikap Dan Perilaku Ibu Nifas
}

\author{
The Influence of Whatsapp Media Education About Lactation Nutrition, \\ Uterine Involution, and Lochea on Knowledge, Attitudes and Behavior of \\ Postpartum Mothers
}

\author{
Ratnaeni $^{1}$, Agussalim Bukhari ${ }^{2}$, Healthy Hidayanty ${ }^{3}$, Nurpudji Astuti \\ Daud $^{2}$,Burhanuddin Bahar ${ }^{3}$, Ni Luh Puti Herli Mastuti ${ }^{4}$ \\ ${ }^{1}$ Magister Kebidanan Sekolah Pascasarjana Universitas Hasanuddin \\ ${ }^{2}$ Fakultas Kedokteran Universitas Hasanuddin \\ ${ }^{3}$ Fakultas Kesehataan Masyarakat Universitas Hasanuddin \\ ${ }^{4}$ Fakultas Kedokteran Universitas Brawijaya \\ 1Email: ennabone95@gmail.com
}

\begin{abstract}
ABSTRAK
Masa nifas yang abnormal menyebabkan masalah seperti sub-involusi uteri dan perdarahan, apabila tidak tertangani dengan cepat dapat berakibat pada kematian ibu. Edukasi merupakan salah satu asuhan untuk meningkatkan pengetahuan, sikap dan perilaku ibu nifas. Tujuan penelitian ini adalah untuk Mengetahui efek edukasi whatsapp tentang gizi laktasi, involusi uteri, dan lochea terhadap pengetahuan, sikap dan perilaku ibu nifas di wilayah kerja RSIA Sitti Khadijah I Muhammadiyah Makassar". Desain Penelitian yaitu quasi experiment dengan one group pre-test dan post-test design. Penelitian dilaksanakan di RSIA Sitti Khadijah I Muhammadiyah Makassar pada bulan Januari s/d Februari tahun 2020. Sampel sebanyak 39 responden. Tekhnik pengambilan sampel menggunakan purposive sampling, intervensi diberikan melalui media whatsapp tentang gizi laktasi, involusi uteri dan lochea selama 14 hari dengan 2 kali pemberian materi dalam sehari dan selesai pembagian materi peneliti melakukan pemantauan group jika materi telah diakses maka nama responden berada pada kolom "Dibaca Oleh" namun jika belum diakses nama responden berada pada kolom "Tersampaikan Ke". Data dianalisis menggunakan uji Mc Nemar. Sebagian besar responden berumur 20-35 tahun yaitu sebanyak 84.6\%, mayoritas pendidikan responden yaitu perguruan tinggi sebanyak $41.0 \%$, responden sebagian besar bekerja sebagai IRT yaitu sebanyak 56.4\%, Sebagian besar responden pendapatan keluarganya 3-5 juta perbulan sebanyak 69.2\% dan sebagian besar responden memiliki jumlah anak 2-4 yaitu sebanyak 43.6\%. Terjadi peningkatan yang signifikan terhadap pengetahuan sebesar $84.6 \%$ dan sikap sebesar $79.5 \%$ setelah pemberian intervensi dengan p-value 0.000. sedangkan pada perilaku konsumsi protein, VIT A dan VIT C masing-masing sebesar $35.9 \%$, 41\% dan $59 \%$ setelah pemberian intervensi dengan p value $<0.05$. Terdapat peningkatan pengetahuan, sikap dan perilaku ibu nifas di wilayah kerja RSIA Sitti Khadijah I Cabang Muhammadiyah Makassar. Dan diharapkan ibu hamil maupun ibu nifas agar memanfaatkan media sosial yang dimiliki khususnya Whatsapp serta diharapkan peneliti selanjutnya agar bisa mengembangkan penelitian ini dengan menggunakan media sosial yang lainnya.
\end{abstract}

Kata Kunci : Edukasi, Media Sosial Whatsapp, Gizi, Ibu Nifas

ABSTRACT

The abnormal period of nifas causes problems such as the sub-involution of utero and bleeding, when it is not handled quickly can result in maternal mortality. Education is one of the upbringing to improve the knowledge, attitudes and behaviors of mother Nifas. The aim of this research is to know the effect of WhatsApp education on lactation, uteri, and Lochea on the knowledge, attitudes and behavior of puerperium in the working area of Sitti Khadijah I Muhammadiyah Makassar ". Research design that is 
quasi experiment with one group pre-Test and post-Test design. The research was conducted in Rsia Sitti Khadijah I Muhammadiyah Makassar in January S/d february year 2020. Sample of 39 respondents. Sampling technique using purposive sampling, intervention is given through WhatsApp media about lactation, utero and Lochea for 14 days with 2 times the provision of materials in a day and completed the division of the research material conducting group monitoring if the material is accessed then the name of the respondent is in the field "read by" but if it has not been accessed the name of the respondent is in the field Data was analyzed using Mc Nemar test. Result: Most of the respondents were 20-35 years old as much as $84.6 \%$, the majority of the education of respondents was the college as much as $41.0 \%$, respondents MOSTLY worked as IRT, which was 56.4\%, most of the family income was 3-5 million per month as many as $69.2 \%$ and most respondents had a total of $2-4$ children as much as $43.6 \%$. There was a significant increase in the knowledge of $84.6 \%$ and an attitude of $79.5 \%$ after the intervention with P-value 0.000. While on the behavioral consumption of proteins, Vit A and vit C respectively at $35.9 \%, 41 \%$ and $59 \%$ after administration of the intervention with P value $<0.05$. There is an increase in the knowledge, attitudes and behaviors of puerperium mothers in the work area of RSIA Sitti Khadijah I Muhammadiyah Branch of Makassar. And expected to be Pregnant and mother Nifas to make use of social media owned especially Whatsapp and Dipleaseto further researchers in order to develop this research using other social media.

Keywords: Education, Social Media Whatsapp, Nutrition, Puerperium

\section{PENDAHULUAN}

Angka Kematian Ibu (AKI) saat ini masih tergolong tinggi padahal seperti yang kita ketahui bahwa (AKI) adalah salah satu indikator yang dapat menggambarkan kesejahteraan masyarakat di suatu Negara dan berdasarkan data yang diperoleh dari WHO jumlah AKI (2015) adalah 216 per 100.000 kelahiran hidup, di Indonesia Tahun 2015 sebesar 309 per 100.000 kelahiran hidup, di Provinsi Sulawesi Selatan tahun 2015 sebesar 99.38 per 100.000 kelahiran hidup, di RSIA Sitti Khadijah I Muhammadiyah Makassar, jumlah AKI 5 tahun terakhir yaitu pada tahun 2015 sebanyak 0 orang, tahun 2016 sebanyak 2 orang, tahun 2017 sebanyak 0 orang, tahun 2018 sebanyak 3 orang dan pada tahun 2019 jumlah AKI sebanyak 1 orang. (WHO.,2015; Dinas
Kesehatan Kota Makassar.,2015; Sutarjo

et al., 2017; Qonitun,U. dan Novitasari,F.,2018)

Masa Nifas yaitu masa setelah lahirnya bayi, plasenta, dan juga selaput sampai enam minggu post partum ( alatalat reproduksi kembali normal seperti sebelum hamil ).( Setyorini \& Mediastuti., 2014)

Masa nifas yang abnormal menyebabkan timbulnya masalah seperti sub-involusi uteri, perdarahan, infeksi, sindrom ASI kurang dan kelainan pada payudara (mastitis), dan apabila komplikasi ini tidak tertangani dengan cepat dan tepat dapat berakibat pada kematian ibu. ( Manuaba et al., 2013;Nurjanah., 2017)

Asuhan pada masa nifas perlu dilakukan karena 50\% kematian ibu terjadi pada masa nifas ( 24 jam pertama 
post partum). Berdasarkan data Direktorat Kesehatan Ibu Tahun 2013 penyebab kematian ibu nifas diantaranya perdarahan $(30,3 \%)$ dan infeksi $(7,3 \%)$. Salah satu faktor predisposisi perdarahan post partum karena subinvolusi uteri yang menyebabkan pengeluran lochea menjadi tidak normal seperti terjadinya pemanjangan periode pengeluaran lochea. Ibu nifas banyak yang belum mengerti dan memahami manfaat dari menyusui, yang mana menyusui dapat mencegah perdarahan karena uterus berkontraksi dengan adanya hisapan bayi oleh karena itu sangat penting untuk dilakukan edukasi pada ibu nifas. (Nugroho.,2014)

Pelaksanaaan edukasi yang selama ini berlangsung di pelayanan kesehatan dianggap kurang berhasil karena edukasi yang diberikan kurang diminati oleh ibu dan hanya bersifat satu arah yang mengakibatkan tidak terjadi komunikasi yang efektif antara ibu dan bidan (Amin,M.A.,2019). Aplikasi yang paling banyak digunakan di dunia saat ini adalah aplikasi Whatsapp yang mana kita dapat mengirim chat yang tanpa batasan karakter, gambar, video, suara dan GPS yang mana media tersebut langsung ditampilkan dan bukan berupa link untuk itu edukasi dengan via whatsapp lebih efektif, efisien, fleksibel dan praktis dibandingkan edukasi dengan cara tradisional (Suryadi, Edi dkk.,2018;Clavier, T et al.,2019).

Berdasarkan latar belakang tersebut maka peneliti mengukur pengaruh edukasi media whatsapp tentang gizi laktasi, involusi uteri, dan lochea terhadap pengetahuan, sikap dan perilaku ibu nifas di wilayah kerja RSIA Sitti Khadijah I Muhammadiyah Makassar.

\section{METODE PENELITIAN}

Penelitian kuantitatif dengan desain Penelitian yaitu quasi experiment dengan one group pre-test dan post-test design. Penelitian ini dilaksanakan di RSIA Sitti Khadijah I Muhammadiyah Makassar. Waktu penelitian yaitu bulan Januari -Februari tahun 2020. Dengan jumlah sampel sebanyak 39 responden yang memenuhi kriteria inklusi berdasarkan tekhnik purposive sampling. Intervensi diberikan berupa edukasi melalui media whatsapp selama 14 hari dengan 2 materi dalam sehari. Data dianalisis menggunakan uji Mc Nemar. Variabel independent yaitu edukasi gizi adalah penyampaian informasi gizi kepada subjek penelitian tentang zat gizi yang dapat 


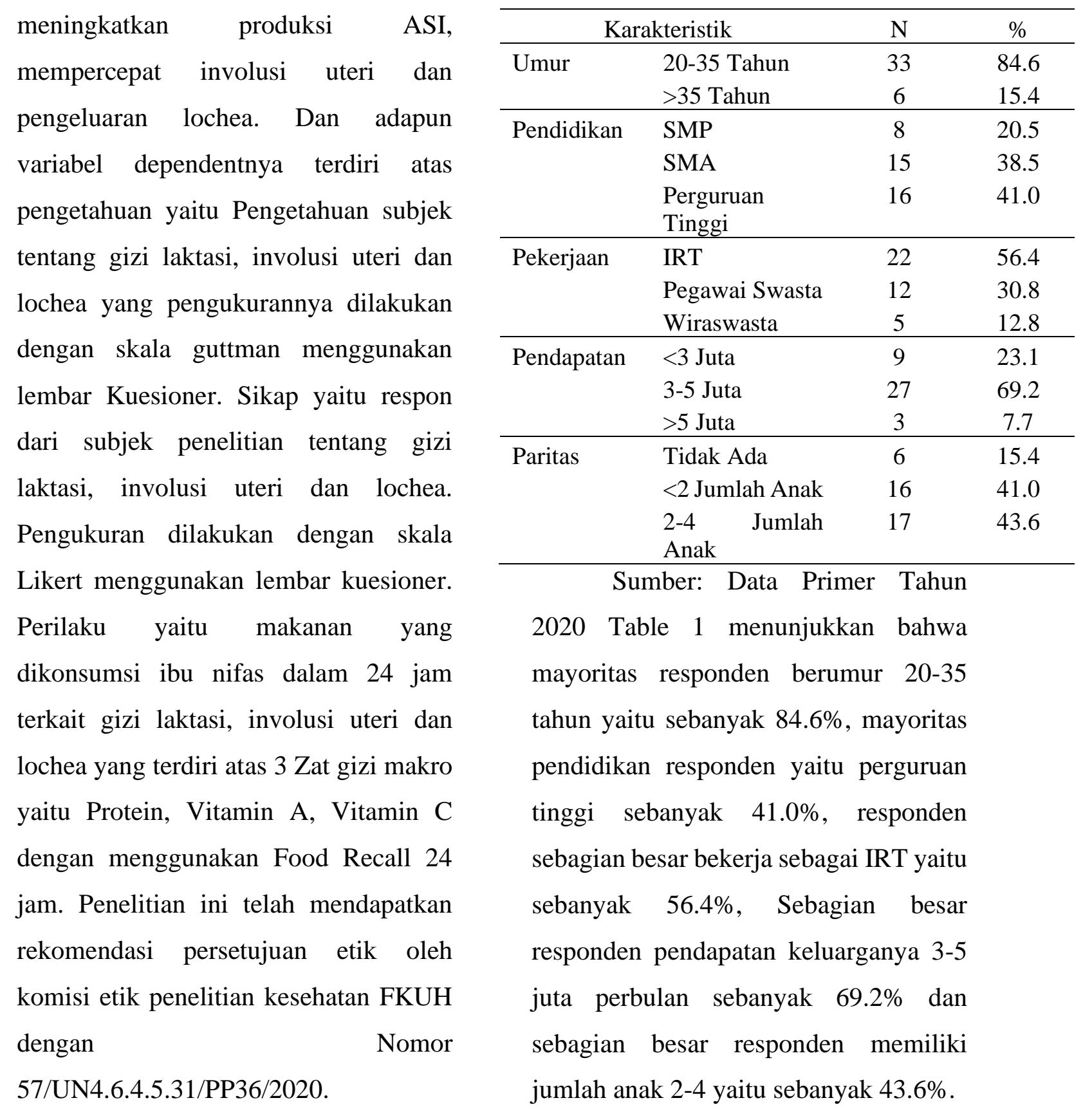

\section{HASIL DAN PEMBAHASAN}

Tabel 1. Distribusi Frekuensi Karakteristik Responden Di Wilayah kerja RSIA Sitti Khadijah I Muhammadiyah Makassar 
a. Pengetahuan

Tabel 2. Distribusi Perbedaan Pengetahuan Responden Sebelum Dan Setelah Edukasi Media Whatsapp Pada Ibu Nifas Di Wilayah Kerja RSIA Sitti Khadijah I Muhammadiyah Makassar

\begin{tabular}{cccccc}
\hline & & \multicolumn{2}{c}{ Setelah } & \multirow{2}{*}{ Total } & Nilai p \\
\cline { 3 - 5 } & $\begin{array}{c}\text { Pengetahuan } \\
\text { Kurang }\end{array}$ & $\begin{array}{c}\text { Pengetahuan } \\
\text { Baik }\end{array}$ & & \\
\hline Sebelum & Pengetahuan Baik & $0(0 \%)$ & $2(5.1 \%)$ & $2(5.1 \%)$ & \\
\cline { 1 - 5 } & $\begin{array}{c}\text { Pengetahuan } \\
\text { Kurang }\end{array}$ & $4(10.3 \%)$ & $33(84.6 \%)$ & $\begin{array}{c}37(94.9 \% \\
)\end{array}$ & $<0.001$ \\
\hline Total & & $4(10.3 \%)$ & $35(89.7)$ & $39100 \%)$ & \\
\hline
\end{tabular}

*Uji Mc Nemar

Berdasarkan tabel 2 dapat dilihat bahwa responden yang memiliki pengetahuan baik sebelum intervensi namun memiliki pengetahuan kurang setelah intervensi sebanyak 0\%. Responden yang memiliki pengetahuan kurang sebelum intervensi namun berubah menjadi pengetahuan baik setelah intervensi sebanyak $84.6 \%$. Nilai $\mathrm{p}$ uji Mc Nemar adalah $<0.001$. Nilai $\mathrm{p}$ value $<$ nilai $\alpha(0.05)$ yang menunjukkan bahwa terdapat perbedaan pengetahuan antara sebelum dan setelah pemberian intervensi edukasi media whatsapp.

Berdasarkan hasil penelitian menunjukkan bahwa responden yang memiliki pengetahuan baik sebelum intervensi namun memiliki pengetahuan kurang setelah intervensi sebanyak 0 responden $(0 \%)$, dan responden yang memiliki pengetahuan kurang sebelum intervensi dan berubah menjadi pengetahuan baik setelah pemberian intervensi sebanyak 33 responden (84.6\%). Ada banyak faktor yang bisa menyebabkan terjadinya peningkatan pengetahuan pada seseorang diantaranya umur, pendidikan maupun pengalaman.

Dari hasil penelitian dapat kita lihat bahwa edukasi dengan media whatsapp mengalami peningkatan pengetahuan sebesar 84.6\% (Tabel 3.11), sedangkan edukasi dengan media/metode yang lain seperti edukasi dengan ceramah peningkatannya sebesar $1.98 \%$ (Sarwani et al., 2014), dengan media booklet sebesar $13.3 \%$ (Ma'munah,M., 2015) dan edukasi melalui penyuluhan peningkatannya sebesar 50.0\% (Saraswati, E.R., 2014). 
Peningkatan pengetahuan yang hanya sedikit pada metode ceramah, booklet dan penyuluhan dibandingkan media whatsapp dikarenakan perbedaan metode yang digunakan, yang mana edukasi dengan menggunakan aplikasi Whatsapp lebih mudah dipahami oleh responden karena materi yang telah dibagikan dapat dibaca berulang-ulang oleh responden kapan dan dimanapun, baik jarak dekat maupun jarak jauh sebelum kegiatan post test dilaksanakan, dan sangat praktis digunakan karena terinstal dalam smartphone dan bisa dibawa kemana-mana. Materi edukasi yang disampaikan melalui media whatsapp lebih menarik karena dilengkapi dengan gambargambar, selain itu lebih murah sehingga memudahkan dan memungkinkan bagi penyuluh untuk memberikan edukasi dan materi sedikit demi sedikit selama 14 hari dengan 2 materi dalam sehari sehingga materi lebih mudah dipahami oleh responden yang tidak memungkinkan jika diberikan dengan metode tatap muka secara langsung (ceramah, konseling maupun penyuluhan) selama 14 hari.
Alasan lainnya yaitu responden banyak yang aktif dalam mengakses whatsapp sehingga edukasi yang disampaikan sangat efektif dibandingkan edukasi dengan cara tradisional.

Semakin sering ibu diberikan edukasi maka pemahaman dan pengetahuan ibu semakin bertambah tentang nutrisi masa nifas dan adapun faktor yang mempengaruhi pengetahuan ibu diantaranya usia, pendidikan, pengalaman dan pekerjaan. Semakin banyak informasi yang masuk maka semakin banyak pula pengetahuan yang didapatkan. (Nikmah,N.,2018)

b. Sikap.

Berdasarkan hasil yang telah diperoleh terkait sikap responden tentang pengaruh edukasi media whatsapp tentang gizi laktasi, involusi uteri dan lochea di RSIA Sitti Khadijah I Muhammadiyah Makassar menunjukkan bahwa sebelum dilakukan intervensi tidak ada seorangpun responden yang memiliki sikap baik, namun setelah diberikan intervensi berupa edukasi dengan media whatsapp terdapat $20.5 \%$ responden yang memiliki 
sikap kurang dan sebanyak $79.5 \%$ responden memiliki sikap baik setelah diberikan intervensi. Dan dari hasil uji SPSS diperoleh nilai $\mathrm{p}$ uji Mc Nemar adalah <0.001. Nilai $\mathrm{p}$ value $<$ nilai $\alpha(0.05)$ yang menunjukkan bahwa terdapat perbedaan sikap antara sebelum dan setelah pemberian intervensi edukasi media whatsapp.

Hasil penelitian menunjukkan bahwa sebelum dilakukan intervensi berupa edukasi via whatsapp, tidak ada satu pun responden yang memiliki sikap baik namun setelah dilakukan intervensi terjadi peningkatan menjadi 31 orang $(79.5 \%)$ yang memiliki sikap baik, sedangkan yang memiliki sikap kurang setelah intervensi sebanyak 8 orang (20.5\%). Hasil penelitian ini terkait sikap ibu nifas tidak disajikan dalam bentuk tabel dikarenakan data frekuensi tidak memenuhi aturan tabel kontigensi 2 x 2 untuk penggunaan Uji Mc Nemar.

Dari hasil diatas sebagian besar responden memiliki sikap baik setelah pemberian intervensi hal ini dikarenakan tingkat pengetahuan yang dimiliki oleh responden setelah pemberian intervensi juga meningkat. Sikap seseorang erat kaitannya dengan pengetahuan yang dimiliki, pada umumnya semakin tinggi tingkat pengetahuan seseorang maka semakin baik pula sikapnya.

Sikap seseorang dipengaruhi oleh beberapa faktor diantaranya pekerjaan, umur, pengalaman pribadi, orang yang dianggap penting, kebudayaan, media massa, pendidikan dan lembaga agama emosional. (Sri Mulyani.,2018).

Dari hasil penelitian ini dapat kita lihat bahwa terjadi peningkatan sikap sebesar $79.5 \%$ jika dibandingkan penelitian yang lain dengan menggunakan media yang sama yaitu media whatsapp yang peningkatannya hanya sebesar 1.52

(Virginia,P.,2016). Peningkatan sikap yang hanya sedikit pada penelitian yang lain dibandingkan dalam penelitian ini bisa dikarenakan metode yang digunakan dalam penelitian ini lebih baik karena materi edukasi diberikan sedikit demi sedikit selama 14 hari sehingga materi lebih mudah dipahami oleh responden, selain itu materi disajikan secara 
menarik dengan memberikan gambar-gambar di setiap materi. Sedangkan edukasi melalui penyuluhan peningkatannya sebesar $100 \%$ ini dikarenakan dalam penelitiannya menggunakan jumlah sampel yang sedikit yaitu hanya 12 responden jadi peneliti lebih fokus memberikan penyuluhan kepada responden.

Berdasarkan dari hasil penelitian dan didukung oleh beberapa penelitian yang lain maka dapat dikatakan bahwa media sosial whatsapp sangat efektif digunakan sebagai media edukasi untuk penyebaran informasi dikarenakan kelebihan medium ini yang tak hanya mampu berkirim pesan melalui kata-kata tetapi juga gambar, audio, video dan dokumen bahkan link-link jaringan internet dan dari kelebihan ini saja sudah mewakili semua media promosi kesehatan yang ada baik dari segi penggunaan (bahan bacaan dan peraga) maupun cara produksinya (media cetak, elektronika dan luar ruang)

\section{c. Perilaku}

Tabel 3. Distribusi Perbedaan Perilaku Konsumsi Protein Responden Sebelum Dan Setelah Edukasi Media Whatsapp Pada Ibu Nifas Di Wilayah Kerja RSIA Sitti Khadijah I Muhammadiyah Makassar

\begin{tabular}{|c|c|c|c|c|c|}
\hline & & \multicolumn{2}{|c|}{ Setelah } & \multirow[b]{2}{*}{ Total } & \multirow[b]{2}{*}{ Nilai $p$} \\
\hline & & Perilaku kurang & $\begin{array}{c}\text { Perilaku } \\
\text { Baik }\end{array}$ & & \\
\hline \multirow[t]{2}{*}{ Sebelum } & $\begin{array}{l}\text { Perilaku } \\
\text { Baik }\end{array}$ & $4(10.3 \%)$ & $13(33.3 \%)$ & $\begin{array}{l}17(43.6 \% \\
)\end{array}$ & \multirow{2}{*}{0.004} \\
\hline & Perilaku kurang & $4(10.3 \%)$ & $18(46.2 \%)$ & $\begin{array}{c}22(56.4 \% \\
)\end{array}$ & \\
\hline Total & & $8(20.5 \%)$ & $31(79.5 \%)$ & 39 100\%) & \\
\hline
\end{tabular}

\section{*Uji Mc Nemar}

Berdasarkan tabel 3 dapat dilihat bahwa responden yang memiliki perilaku konsumsi protein baik sebelum intervensi namun memiliki perilaku konsumsi protein kurang setelah intervensi sebanyak $10.3 \%$. Responden yang memiliki perilaku konsumsi protein kurang sebelum intervensi namun berubah menjadi perilaku konsumsi protein baik setelah intervensi sebanyak 46.2\%. Nilai p uji Mc Nemar adalah 0.004 yang mana nilai $\mathrm{p}$ value < 
nilai $\alpha(0.05)$ yang menunjukkan bahwa

protein sebelum dan setelah pemberian terdapat perbedaan perilaku konsumsi intervensi edukasi media whatsapp.

Table 4. Distribusi Perbedaan perilaku Konsumsi VIT A Responden Sebelum Dan Setelah Edukasi Media Whatsapp Pada Ibu Nifas Di Wilayah Kerja RSIA Sitti Khadijah I Muhammadiyah Makassar

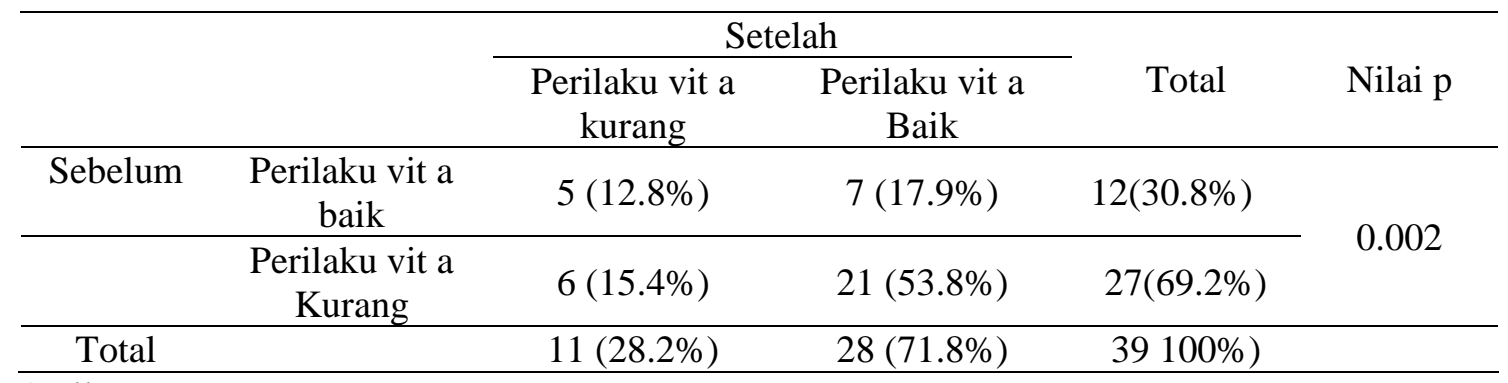

*Uji Mc Nemar

Berdasarkan tabel 4 dapat dilihat bahwa responden yang memiliki perilaku konsumsi VIT A baik sebelum intervensi namun memiliki perilaku konsumsi VIT A kurang setelah intervensi sebanyak $12.8 \%$. Responden yang memiliki perilaku konsumsi VIT A kurang sebelum intervensi namun berubah menjadi perilaku konsumsi VIT A baik setelah intervensi sebanyak 53.8\%. Nilai p uji Mc Nemar adalah 0.002 yang mana nilai $\mathrm{p}$ value $<$ nilai $\alpha$ (0.05) yang menunjukkan bahwa terdapat perbedaan perilaku konsumsi VIT A sebelum dan setelah pemberian intervensi edukasi media whatsapp.

Table 5 Distribusi Perbedaan perilaku Konsumsi VIT C Responden Sebelum Dan Setelah Edukasi Media Whatsapp Pada Ibu Nifas Di Wilayah Kerja RSIA Sitti Khadijah I Muhammadiyah Makassar

\begin{tabular}{|c|c|c|c|c|c|}
\hline & & \multicolumn{2}{|c|}{ Setelah } & \multirow[b]{2}{*}{ Total } & \multirow[b]{2}{*}{ Nilai $p$} \\
\hline & & $\begin{array}{c}\text { Perilaku vit } \mathrm{C} \\
\text { kurang }\end{array}$ & $\begin{array}{c}\text { Perilaku vit C } \\
\text { Baik }\end{array}$ & & \\
\hline \multirow[t]{2}{*}{ Sebelum } & $\begin{array}{l}\text { Perilaku vit c } \\
\text { baik }\end{array}$ & $0(0 \%)$ & $2(5.1 \%)$ & $2(5.1 \%)$ & \multirow{2}{*}{$<0.001$} \\
\hline & $\begin{array}{c}\text { Perilaku vit c } \\
\text { Kurang }\end{array}$ & $14(35.9 \%)$ & $23(59.0 \%)$ & $\begin{array}{c}37(94.9 \% \\
)\end{array}$ & \\
\hline Total & & $14(35.9 \%)$ & $25(64.1 \%)$ & $39100 \%)$ & \\
\hline
\end{tabular}

*Uji Mc Nemar

Berdasarkan tabel 5 dapat dilihat bahwa responden yang memiliki perilaku konsumsi VIT C baik sebelum intervensi namun berubah menjadi perilaku konsumsi VIT C kurang setelah intervensi sebanyak 0\%. Responden 
yang memiliki perilaku konsumsi VIT C kurang sebelum intervensi dan berubah menjadi perilaku konsumsi VIT C baik setelah intervensi sebanyak $59.0 \%$. Nilai p uji Mc Nemar adalah <0.001 yang mana nilai $\mathrm{p}$ value $<$ nilai $\alpha(0.05)$ yang menunjukkan bahwa terdapat perbedaan perilaku konsumsi VIT C sebelum dan setelah pemberian intervensi edukasi media whatsapp.

Berdasarkan hasil penelitian diperoleh data yaitu pada variabel perilaku konsumsi protein, responden yang memiliki perilaku baik sebelum intervensi namun berubah menjadi perilaku konsumsi protein kurang setelah intervensi sebanyak 4 responden $(10.3 \%)$ dan responden yang memiliki perilaku konsumsi protein kurang sebelum intervensi dan berubah menjadi perilaku konsumsi protein baik setelah pemberian intervensi sebanyak 18 responden $(46.2 \%)$.

Pada perilaku konsumsi VIT A, responden yang memiliki perilaku baik sebelum intervensi namun berubah menjadi perilaku konsumsi VIT A kurang setelah intervensi sebanyak 5 responden $(12.8 \%)$ dan responden yang memiliki perilaku konsumsi VIT A kurang sebelum intervensi dan berubah menjadi perilaku konsumsi VIT A baik setelah pemberian intervensi sebanyak 21 responden $(53.8 \%)$.

Pada perilaku konsumsi VIT C, responden yang memiliki perilaku baik sebelum intervensi namun berubah menjadi perilaku konsumsi VIT $\mathrm{C}$ kurang setelah intervensi sebanyak 0 responden (0\%). Responden yang memiliki perilaku konsumsi VIT $\mathrm{C}$ kurang sebelum intervensi dan berubah menjadi perilaku konsumsi VIT C baik setelah intervensi ada 23 responden $(59.0 \%)$.

Perubahan perilaku seseorang terbentuk setelah ada perubahan pengetahuan serta perubahan pada sikap. Dan dengan adanya sarana dan prasarana pada aplikasi whatsapp yang bisa dikatakan lengkap maka ini akan mempermudah penyampaian informasi sehingga mempengaruhi perilaku responden. (Amalia, dkk.,2018)

Hasil penelitian Erlin Retna Saraswati (2014) menunjukkan secara jelas bahwa terjadi peningkatan perilaku sebelum dan setelah diadakan penyuluhan terkait praktik ibu dalam pemberian ASI minnggu pertama yakni tingkat perilaku kategori cukup sebelum penyuluhan sebanyak 6 orang $(50 \%)$ berkurang menjadi 4 orang $(33.3 \%)$ setelah penyuluhan. Sementara perilaku 
kategori baik sebelum penyuluhan sebanyak 6 orang $(50 \%)$ bertambah setelah dilakukan penyuluhan menjadi 8 orang $(66.7 \%)$. Seperti yang kita lihat bahwa peningkatan perilaku pada penelitian Erlin Retna Saraswati tersebut hanya sedikit yaitu sebesar $16.7 \%$ dibandingkan peningkatan pada penelitian ini yaitu perilaku konsumsi protein sebesar 35.9\% (Tabel 3.12), perilaku konsumsi VIT A sebesar $41 \%$ (Tabel 3.13), perilaku konsumsi VIT C sebesar 59.0\% (Tabel 3.14). hal ini dikarenakan perbedaan metode yang digunakan yang mana edukasi dengan menggunakan media whatsapp materinya lebih mudah dipahami karena dapat dibaca berulang-ulang oleh responden kapan dan dimanapun, selain itu lebih murah sehingga materi edukasi bisa dibagikan sedikit demi sedikit selama 14 hari yang tidak memungkinkan jika menggunakan metode penyuluhan selama 14 hari dan materi edukasi melalui media whatsapp lebih menarik karena dilengkapi gambar pada setiap materinya.

Dari hasil penelitian ini, dapat kita lihat bahwa terjadi peningkatan perilaku yaitu perilaku konsumsi protein sebesar $35.9 \%$ (Tabel 3.12), perilaku konsumsi VIT A sebesar $41 \%$ (Tabel
3.13), perilaku konsumsi VIT C sebesar $59.0 \%$ (Tabel 3.14). Dan jika dibandingkan dengan penelitian yang lain dengan menggunakan media yang sama yaitu aplikasi whatsapp peningkatan perilakunya hanya sebesar $2.87 \%$ (Virginia,P.,2016). Hal ini dikarenakan dalam penelitian ini materi edukasi diberikan sedikit demi sedikit selama 14 hari dan dalam sehari materi diberikan 2 kali yaitu pada pagi hari dan malam hari sehingga memudahkan responden untuk mencerna dan memahami materi yang disampaikan, selain itu dalam penelitian ini materi dikemas secara menarik dengan cara menyertakan gambar agar responden tertarik untuk mengakses materi yang disampaikan dan bagi responden yang kurang mengerti pada materi yang diberikan,mereka dapat melihat pada gambar yang menyertai pada setiap materi edukasi.

Sedangkan melalui penyuluhan peningkatannya sebesar $16.7 \%$ (Saraswati,E.R.,2014) sedangkan peningkatan perilaku pada penelitian ini yaitu perilaku konsumsi protein sebesar $35.9 \%$ (Tabel 3.12), perilaku konsumsi VIT A sebesar 41\% (Tabel 3.13), perilaku konsumsi VIT C sebesar $59.0 \%$ (Tabel 3.14). Sedikitnya peningkatan 
sikap pada penelitian yang lain dikarenakan perbedaan metode yang digunakan yang mana edukasi dengan menggunakan media whatsapp materinya lebih mudah dipahami karena dapat dibaca berulang-ulang oleh responden kapan dan dimanapun, selain itu lebih murah sehingga materi edukasi bisa dibagikan sedikit demi sedikit selama 14 hari yang tidak memungkinkan jika menggunakan metode penyuluhan selama 14 hari dan materi edukasi melalui media whatsapp lebih menarik karena dilengkapi gambar pada setiap materinya.

Alasan lain sedikitnya jumlah peningkatan skor perilaku pada penelitian yang lain baik menggunakan media yang sama yaitu whatsapp maupun menggunakan media yang lain yaitu penyuluhan bisa dikarenakan alat pengukuran perilaku yang digunakan berupa kuesioner beda halnya dalam penelitian ini, pengukuran perilakunya dilakukan dengan menggunakan food recall 24 jam.

\section{SIMPULAN DAN SARAN}

Terdapat peningkatan pengetahuan, sikap dan perilaku ibu nifas di wilayah kerja RSIA Sitti Khadijah I Cabang Muhammadiyah
Makassar. Diharapkan ibu hamil maupun ibu nifas agar memanfaatkan media sosial yang dimiliki khususnya Whatsapp serta diharapkan peneliti selanjutnya agar bisa mengembangkan penelitian ini dengan menggunakan media sosial yang lainnya.

\section{DAFTAR PUSTAKA}

(Amalia, dkk, 2018). Pengaruh Edukasi Gizi Terhadap Pengetahuan Dan Praktik Calon Ibu Dalam Pendegahan Kurang Energy Kronik Ibu Hamil. Jurnal Kesehatan Masyarakat. Vol. 5 (5) ISSN:23563346

(Clavier, \& Veber, 2019). Use of the Smartphone App WhatsApp as an E-Learning Method for Medical Residents : Multicenter Controlled Randomized Trial Corresponding Author:, 7, 1-10.

(Dinas Kesehatan kota Makassar (Dinkes), 2015). Profil kesehatan kota Makassar tahun 2015. Diakses pada tanggal 1 september 2019.

(Fitriani, 2016). Pengaruh Motivasi Belajar Dan Disiplin Terhadap Hasil Belajar IPS Siswa Di SMP Karya Indah Kecamatan Tapung. Jurnal peKA. Vol.4 (2). ISSN: 2337-652x

(Issuryanti, 2017). Pengaruh Edukasi Melalui Media Whatsapp Terhadap Peningkatan Pengetahuan Ibu Dalam Memberikan ASI Eksklusif. (Tesis). Yogyakarta: Universitas Gadjah Mada. 
Kemenkes RI. infodatin-asi. Situasi Dan Analisis Asi Eksklusif. Jakarta: Kemenkes RI: 2014

Kemenkes RI. infodatin-ibu (AKI Di Indonesia). Situasi Kesehatan Ibu. Jakarta: Kemenkes RI: 2014

(Ma'munah, 2015). Pengaruh Pendidikan Kesehatan Dengan Booklet Terhadap Pengetahuan Ibu Laktasi Di Wilayah Kerja Puskesmas Ciputat Timur. Program Studi Ilmu Keperawatan Fakultas Kedokteran Dan Ilmu Kesehatan Universitas Islam Negeri Syarif Hidayatullah. Jakarta.

(Mujiran, dkk, 2019). Relationship Of The Level Of Knowledge About Hypertension With Attitude In The Prevention of Complication of Hypertension In Elderly Participants Prolahis Public Health Center Jenawi Karanganyar. Jurnal Ilmiah Kesehatan dan Aplikasinya. Vol. 7 (2). ISSN: 2303-3746

(Mulyani, 2018). The Correlation Between Knowledge And Attitude Of Postpartum Mother Toward Contraception Amenorhoe Lactation Method. Jurnal Ilmiah Kesehatan dan Aplikasinya. Vol. 6 (2). ISSN: 2303-3746

(Nelwatri, 2015). Pengaruh Inisiasi Menyusu Dini ( Imd ) Terhadap Involusi Uterus Pada Ibu Bersalin Di Bps Kota Padang Tahun 2013.Jurnal Ipteks Terapan. (online). 83-87.

(Nikmah, 2018). Hubungan Pemberian KIE Dengan Pengetahuan Nutrisi Masa Nifas Di Puskesmas Kedungdung Sampang. Seminar
Nasional Dan Presentasi HasilHasil Penelitian Pengabdian Masyarakat (online). 0-1.

(Nugroho, T.D., dkk, 2014). Asuhan Kebidanan 3 Nifas. Nuha Medika: Yogyakarta.

(Nurjanah, 2017). Gambaran Lama Pengeluaran Lochea Dan Pola Menyusui Pada Ibu Post Partum Di Puskesmas Pajang Dan Banyuanyar Surakarta. Skipsi tidak diterbitkan. Surakarta. Program Studi Keperawatan Fakultas Ilmu Kesehatan Universitas Muhammadiyah Surakarta.

(Prasetya, A. W et Al, 2019). Pengaruh Media Sosial Dalam Peningkatan Pengetahuan Dan Sikap Siswa Perokok Terhaddap Pencegahan Stain Gigi Di SMA Negeri 1 Sei Lepan Kabupaten Langkat Ttahun 2019.3 (1), 1-61.

(Qonitun, 2018). Studi Persalinan Kala Iv Pada Ibu Bersalin Yang Melakukan Inisiasi Menyusu Dini ( Imd ) Di Ruang Mina Rumah Sakit Muhammadiyah Turban. Jurnal Kesehatan. 11(1), 1-8.

(Rahayu, 2018). Efektivitas Bengkung Dan Gurita Terhadap Involusi Uterus Dan Pengeluaran Lochea Di Puskesmas Keeling Kabupaten Kendari. JIKK. III(4).

(Rahayu Dan Sugita, 2015). Effect Of Pineapple Juice On Decresing Rate Of Fundal Height And Wound Healing Process In Perineum Of Post Partum Women. Department Obstetrics Of Poltekkes Surakarta.. Volume 8, No.1. 
Riset Kesehatan Dasar (Riskesdas). (2018). Badan penelitian dan pengembangan kesehatan kementerian RI tahun 2018. http://www.depkes.go.id/resources/ download/infoterkini/materirakorp op_2018/Hasil\%20Riskesdas\%201 8.pdf. Diakses 02 september 2019

(Saraswati, 2014). Pengaruh Penyuluhan Cara Menyusui Yang Benar Terhadap Perilaku Pemberian ASI Minggu Pertama Pada Ibu Nifas Di RS PKU Muhammadiyah Yogyakarta. Program Studi Ilmu Keperawatan Sekolah Tinggi Ilmu Kesehatan 'Aisyiyah. Yogyakarta.

(Setyorini \& Mediastuti, 2014). Implementasi Kebijakan Program Nasional Masa Nifas Pada Bidan Praktik Swasta. Jurnal Kebidanan Dan Keperawatan. 10(2).

(Sugiyono, 2017). Metodologi Penelitian. Alfabeta: Bandung.

(Suryadi \& Ginanjar, 2018). Penggunaan Sosial Media Whatsapp Dan Pengaruhnya Terhadap Disiplin Belajar Peserta Didik Pada Mata Pelajaran Pendidikan Agama Islam. Jurnal Pendidikan Islam. 07(01)
(Sutarjo dkk, 2018). Data dan Informasi, Profil Kesehatan Iindonesia 2017. Kemenkes. Download : Http://Www. Pusdatin. Kemenkes. Go. Id/Resources/Download/Pusdatin/P rofil-Kesehatan - Indonesia/Data Dan - Informasi Profil - Kesehatan - Indonesia - 2017. Pdf. Tanggal 22 Oktober 2019.

(Virginia, 2016). Pengaruh Edukasi Media Sosial ( WHATSAPP MESSENGER ) Terhadap Tingkat Penggunaan Obat Keras Yang Rasional Di Masyarakat. Purwokerto.

(Wibisono, 2017). Efektivitas Penggunaan Grup Sosial Media Whatsapp Sebagai Media Edukasi Penanganan Pertama Cedera Musculoskeletal Pada Pelatih Sepakbola. Program Studi Pendidikan Kepelatihan Olahraga Fakultas Ilmu Keolahragaan Universitas Negeri Yogyakarta. Yogyakarta

(Yuneta dkk, 2019). The Correlation Between Mother's Knowledge With Nutritional Status Of Toddters In Wonorejo Village Karanganyar Regency. Jurnal Ilmiah Kesehatan Dan Aplikasinya. Vol. 7(1) ISSN: 2303-3746 